\title{
New insights into ion regulation of cephalopod molluscs: a role of epidermal ionocytes in acid-base regulation during embryogenesis
}

\author{
Marian Y. Hu, ${ }^{1 *}$ Yung-Che Tseng, ${ }^{2 *}$ Li-Yih Lin, ${ }^{3}$ Po-Yen Chen, ${ }^{3}$ Mireille Charmantier-Daures, ${ }^{4}$ \\ Pung-Pung Hwang, ${ }^{2}$ and Frank Melzner ${ }^{1}$ \\ ${ }^{1}$ Leibniz-Institute of Marine Sciences, Kiel, Germany; ${ }^{2}$ Institute of Cellular and Organismic Biology, Academia Sinica, \\ Nangang, Taipei, Taiwan, Republic of China (ROC); ${ }^{3}$ Department of Life Science, National Taiwan Normal University, \\ Taipei, Taiwan, ROC; and ${ }^{4}$ Equipe Adaptation Ecophysiologique et Ontogenèse, UMR 5119 Ecolag, Université Montpellier \\ 2, Montpellier, France
}

Submitted 1 March 2011; accepted in final form 29 September 2011

Hu MY, Tseng YC, Lin LY, Chen PP, Charmantier-Daures M, Hwang PP, Melzner F. New insights into ion regulation of cephalopod molluscs: a role of epidermal ionocytes in acid-base regulation during embryogenesis. Am J Physiol Regul Integr Comp Physiol 301: R1700-R1709, 2011. First published October 5, 2011; doi:10.1152/ajpregu.00107.2011. - The constraints of an active life in a pelagic habitat led to numerous convergent morphological and physiological adaptations that enable cephalopod molluscs and teleost fishes to compete for similar resources. Here, we show for the first time that such convergent developments are also found in the ontogenetic progression of ion regulatory tissues; as in teleost fish, epidermal ionocytes scattered on skin and yolk sac of cephalopod embryos appear to be responsible for ionic and acid-base regulation before gill epithelia become functional. Ion and acid-base regulation is crucial in cephalopod embryos, as they are surrounded by a hypercapnic egg fluid with a $\mathrm{PCO}_{2}$ between 0.2 and $0.4 \mathrm{kPa}$. Epidermal ionocytes were characterized via immunohistochemistry, in situ hybridization, and vital dye-staining techniques. We found one group of cells that is recognized by concavalin A and MitoTracker, which also expresses $\mathrm{Na}^{+} / \mathrm{H}^{+}$exchangers (NHE3) and $\mathrm{Na}^{+}-\mathrm{K}^{+}$-ATPase. Similar to findings obtained in teleosts, these NHE3-rich cells take up sodium in exchange for protons, illustrating the energetic superiority of NHE-based proton excretion in marine systems. In vivo electrophysiological techniques demonstrated that acid equivalents are secreted by the yolk and skin integument. Intriguingly, epidermal ionocytes of cephalopod embryos are ciliated as demonstrated by scanning electron microscopy, suggesting a dual function of epithelial cells in water convection and ion regulation. These findings add significant knowledge to our mechanistic understanding of hypercapnia tolerance in marine organisms, as it demonstrates that marine taxa, which were identified as powerful acid-base regulators during hypercapnic challenges, already exhibit strong acid-base regulatory abilities during embryogenesis.

gill; embryonic development; mitochondrion-rich cells; squid; cuttlefish

CEPHALOPODS ARE EXCLUSIVELY marine invertebrates that have a high degree of mobility, high metabolic rates, well-developed neuronal systems and efficient sensory organs $(6,25,30,58)$. It is believed that these features are derived from the evolutionary competition of cephalopods and fish $(46,48)$. Owing to their active lifestyle, marine invertebrates, such as cephalopods and crustaceans, as well as marine vertebrates (e.g., fish), are also powerful acid-base regulators that actively maintain their

\footnotetext{
* These authors contributed equally to the present work.
}

Address for reprint requests and other correspondence: P.-P. Hwang, Institute of Cellular and Organismic Biology, Academia Sinica, Nangang, Taipei, Taiwan, ROC (e-mail: pphwang@gate.sinica.edu.tw). hemolymph and blood $\mathrm{pH}$ within tight boundaries to protect plasma proteins and especially to protect their $\mathrm{pH}$-sensitive respiratory pigments, from acidosis $(10,15,24,47,67)$.

In marine crustaceans, the gill was identified as a major site for ionic regulation, enabling the active secretion of acid-base equivalents into the surrounding seawater by involving primarily $\mathrm{Na}^{+} / \mathrm{H}^{+}$and $\mathrm{HCO}_{3}^{-} / \mathrm{Cl}^{-}$exchange mechanisms to maintain extracellular $\mathrm{pH}$ homeostasis $(7,67,68)$. These epithelia are rich in $\mathrm{Na}^{+}-\mathrm{K}^{+}$-ATPase (NKA), which provides the driving force for a variety of other secondary active transport processes, such as apical $\mathrm{Na}^{+} / \mathrm{H}^{+}$exchangers (NHE) and $\mathrm{Na}^{+}$dependent $\mathrm{Cl}^{-} / \mathrm{HCO}_{3}^{-}$exchangers (NBCs) that can extrude protons and import $\mathrm{HCO}_{3}^{-}(4,54)$. Therefore, NKA is regarded as an excellent marker for the ion-regulatory capacity of a given tissue (18).

Recently, it has been shown that gills of cephalopods also exhibit high-NKA concentrations in basolateral membranes of the inner, transport active epithelium of the third-order gill lamellae. Furthermore, these NKA-rich cells express acid-base regulatory proteins, such as NBCs, carbonic anhydrase (CA) and V-type $\mathrm{H}^{+}$-ATPase $(28,29)$.

Analogous to the situation in cephalopod molluscs and crustaceans, gill epithelia, kidneys, and intestine are also the main sites of ion and acid-base regulation in fish $(15,20,33$, $36)$. While the intestine is mainly important for the secretion of $\mathrm{HCO}_{3}^{-}$and $\mathrm{CaCO}_{3}$ precipitation (21), specialized cells, socalled mitochondrion-rich cells (MRCs), were identified as the main sites of ionic regulation in teleost gill epithelia (for a review, see Ref. 33).

In contrast to adults, the early life stages of fish show ontogeny-specific alternative sites for ion regulation. Before gill epithelia are fully developed, scattered epidermal ionocytes on the skin mediate ion and acid-base balance $(27,34,40,49)$. Recently, functional genomics and immunohistological studies have revealed the embryonic yolk-sac epithelium to be the major site for osmoregulation in teleosts [see reviews by Hwang (31) and Hwang and Perry (34)]. Such an ontogenydependent shift in the location of ion-regulatory epithelia has also been demonstrated in marine crustaceans (7-9). For example, decapodit stages of the brown shrimp Crangon crangon exhibit NKA-rich ionocytes in the branchiostegite epithelium. These disappear in juveniles, and positive NKA immunoreactivity is found in cells of the gill lamellae (9).

In contrast to decapod crustaceans and teleost fish, the comparatively stenohaline cephalopod molluscs are weak osmoregulators. Their body fluids are slightly hypoosmotic (cuttlefish Sepia officinalis) or isoosmotic (squid Lolliguncula 
brevis) with respect to the environmental seawater $(53,55)$, a feature that is probably closely related to their comparatively thin (and ion-permeable) skin, which serves as a respiratory organ (41). Nevertheless, the ability to regulate extracellular $\mathrm{pH}$ must already be very important for the developing cephalopod embryo due to high metabolic rates toward the end of development and the egg capsule acting as a diffusion barrier for respiratory gases (e.g., $\mathrm{O}_{2}$ and $\mathrm{CO}_{2}$ ). High $\mathrm{PCO}_{2}$ (up to 0.4 $\mathrm{kPa}$ ) builds up in the egg perivitelline fluid (PVF) to drive excretory flux of metabolic $\mathrm{CO}_{2}$. The consequence is a comparatively low PVF $\mathrm{pH}$ of $<7.4$ toward the end of embryonic development (23). It can be hypothesized from these findings that already the developing embryo needs potent acid-base regulatory machinery to eliminate protons from body fluids to cope with hypercapnia-induced acidosis.

This work addresses the question of how far in the early developmental stages of cephalopod molluscs do ion regulatory epithelia control their acid-base homeostasis through active secretion of proton equivalents. The anatomical and morphological features of cephalopod embryos prompted us to formulate the hypothesis that the yolk epithelium may constitute a major site of acid-base regulation, as it is well perfused with hemolymph and accounts for up to $30-50 \%$ of the embryos total body surface $(1,39,62,63)$.

We used the early life stages of cuttlefish (S. officinalis) and squid (Sepioteuthis lessoniana) to demonstrate sites of ion regulation via immunohistochemical, in situ hybridization, vital dye staining, and electrophysiological methods.

\section{MATERIALS AND METHODS}

Experimental animals. S. lessoniana egg clusters were collected in Aodi, Taiwan (Republic of China) in July 2010 and June 2011 by scuba diving and reared in a closed recirculating system (400 1 total volume, nitrification filter, salinity $31-32$, temperature $26^{\circ} \mathrm{C}$, constant 12:12-h dark-light cycle) at the Institute of Cellular and Organismic Biology, Academia Sinica. S. officinalis egg clusters were collected in Luc sur Mer, France, in May 2010. Cuttlefish eggs were raised at the Leibniz-Institute of Marine Sciences (IFM-GEOMAR), Kiel, Germany, in a closed recirculating system $(1,2001$ total volume, protein skimmer, nitrification filter, UV disinfection unit, salinity 31-32, temperature $15^{\circ} \mathrm{C}$ constant $12: 12$-h dark-light cycle).

NKA activity assay. NKA activity was measured in whole animal crude extracts in a coupled enzyme assay with pyruvate kinase and lactate dehydrogenase using the method of Allen and colleagues (57), as described by Melzner et al. (42). Crude extracts were obtained by quickly homogenizing the tissue samples in ice-cold buffer $[50 \mathrm{mM}$ imidazole, $\mathrm{pH}$ 7.8, $250 \mathrm{mM}$ sucrose, $1 \mathrm{mM}$ EDTA, $5 \mathrm{mM} \beta$-mercaptoethanol, $0.1 \%(\mathrm{w} / \mathrm{v})$ deoxycholate, proteinase inhibitor cocktail from Sigma-Aldrich (Taufkirchen, Germany; cat. no. P8340)]. Cell debris was removed by centrifugation for $10 \mathrm{~min}$ at $1,000 \mathrm{~g}$ and $4^{\circ} \mathrm{C}$. The supernatant was used as a crude extract. The reaction was started by adding $10 \mu \mathrm{l}$ of the sample homogenate to the reaction buffer containing $100 \mathrm{mM}$ imidazole, pH 7.8, $80 \mathrm{mM} \mathrm{NaCl}, 20 \mathrm{mM} \mathrm{KCl}, 5$ $\mathrm{mM} \mathrm{MgCl} 2,5 \mathrm{mM}$ ATP, $0.24 \mathrm{mM} \mathrm{Na}\left(\mathrm{NADH}_{2}\right), 2 \mathrm{mM}$ phosphoenolpyruvate, about $12 \mathrm{U} / \mathrm{ml} \mathrm{PK}$, and $17 \mathrm{U} / \mathrm{ml} \mathrm{LDH}$, using a PK/LDH enzyme mix (Sigma-Aldrich). The oxidation of NADH coupled to the hydrolysis of ATP was followed photometrically at $15^{\circ} \mathrm{C}$ in a DU 650 spectrophotometer (Beckman Coulter, Brea, CA). The fraction of NKA activity in total ATPase activity was determined by the addition of $17 \mu \mathrm{l}$ of $5 \mathrm{mM}$ ouabain to the assay. Each sample was measured in sextuples.

RNA probe synthesis. The partial sequence of NKA (GQ153672.1) cDNA was obtained by PCR (forward 5'-TGAAGAAGATGTG-
GAVGAAGGCG-3' and reverse 5'-CGGATGAATGCTGTGAHCTGATAC-3') amplification and inserted into the pGEM-T easy vector (Promega, Madison, WI, USA) for the synthesis of anti-sense and sense RNA probes. The inserted fragments were amplified with the T7 and SP6 primers by PCR, and the products were used as templates for the in vitro transcription with T7 and SP6 RNA polymerase (Roche, Penzberg, Germany), respectively, in the presence of digoxigenin (dig)-UTP. Dig-labeled RNA probes were examined with RNA gels, and dot-blot assays were used to confirm quality and concentration. For dot-blot assays, synthesized probes and standard RNA probes were spotted on nitrocellulose membrane, according to the manufacturer's instructions. After cross-linking and blocking, the membrane was incubated with an alkaline phosphatase-conjugated anti-dig antibody and stained with nitro blue tetrazolium (NBT) and 5-bromo-4chloro-3-indolyl phosphate (BCIP).

In situ hybridization. Fixed samples were hydrated in a descending ethanol series and rinsed with PBST (0.1\% Tween 20, pH 7.4) and incubated for $20 \mathrm{~min}$ in proteinase $\mathrm{K}$ (Sigma) solution $(10 \mu \mathrm{g} / \mathrm{ml}$ in PBST). Samples were first rinsed in a glycin solution $(4 \mathrm{mg} / \mathrm{ml}$ PBST), washed with PBST, and then washed 3 times for 10 min with triethanolamine. At the last wash, $2.3 \mu \mathrm{l}$ acetic acid anhydrate per milliliter were added at the beginning and the end of the incubation. Samples were washed in PBST, then incubated in 4\% PFA in PBST for $60 \mathrm{~min}$. Afterward, samples were first washed in PBST and then in $2 \times \mathrm{SSC}$ before they were incubated in $2 \times \mathrm{SSC}$ for $15 \mathrm{~min}$ at $70^{\circ} \mathrm{C}$. The samples were now transferred to a $2 \times \mathrm{SSC} /$ hybridization buffer (HyB) (1:1). The hybridization buffer (HyB) contained $60 \%$ formamide, $2 \times \mathrm{SSC}$, and $0.1 \%$ Tween 20 for $10 \mathrm{~min}$ at $70^{\circ} \mathrm{C}$. Prehybridization was performed in $\mathrm{HyB}+$, which is the hybridization buffer supplemented with $200 \mu \mathrm{g} / \mathrm{ml}$ yeast tRNA, $1 \times$ Denhardt's reagent and $100 \mu \mathrm{g} / \mathrm{ml}$ heparin for $2 \mathrm{~h}$ at $57^{\circ} \mathrm{C}$. After prehybridization, samples were incubated in the RNA probe diluted 1:2,000 in $\mathrm{HyB}+$ at $57^{\circ} \mathrm{C}$ overnight for hybridization. Samples were then washed at $65^{\circ} \mathrm{C}$ for $10 \mathrm{~min}$ in $100 \% \mathrm{HyB}, 75 \% \mathrm{HyB}$ and $25 \% 2 \times \mathrm{SSC}, 10 \mathrm{~min}$ in $50 \% \mathrm{HyB}$, and $50 \% 2 \times \mathrm{SSC}, 10 \mathrm{~min}$ in $25 \% \mathrm{HyB}$, and $75 \%$ $2 \times \mathrm{SSC}$, and twice for $30 \mathrm{~min}$ in $2 \times \mathrm{SSC}$ to which $0.1 \%$ CHAPS has been added and incubated at $70^{\circ} \mathrm{C}$. Samples were washed twice for 10 $\mathrm{min}$ in $\mathrm{MAB}$ at room temperature.

After serial washings, samples were incubated for $1 \mathrm{~h}$ in preblocking solution containing 1\% BSA in maleic acid buffer (MAB-B) and then afterward transferred to a blocking solution containing $20 \%$ sheep serum and $80 \%$ MAB-B for $2 \mathrm{~h}$. Samples were then incubated in 1:2,000 alkaline phosphatase-conjugated anti-dig antibody in blocking solution overnight. After incubation, samples were washed twice with MAB-B for $45 \mathrm{~min}$, twice in $\mathrm{MAB}$ for $45 \mathrm{~min}$, another four times in MAB for $30 \mathrm{~min}, 5 \mathrm{~min}$ in NTM-T solution $(100 \mathrm{mM} \mathrm{NaCl}$, $1 \mathrm{mM}$ Tris, $50 \mathrm{mM} \mathrm{MgCl}_{2}$, and $0.1 \%$ Tween, $\mathrm{pH}$ 9.5), and then transferred to the staining buffer. The staining reaction was held with NBT and BCIP in NTM-T $(1: 100)$ at $37^{\circ} \mathrm{C}$ until the signal was sufficiently strong. The staining reaction was terminated by several washings in Milli-Q water. In situ hybridizations using sense probes served as a negative control.

Immunohistochemical staining. For immunocytochemistry on paraffin sections, whole animals were fixed by direct immersion for $24 \mathrm{~h}$ in Bouin's fixative followed by rinsing in $70 \%$ ethanol. Samples were fully dehydrated in graded ethanol series and embedded in Paraplast (Paraplast Plus, Sigma, P3683). Sections of $4 \mu \mathrm{m}$ were cut on a Leitz Wetzlar microtome, collected on poly-L-lysine-coated slides, and stored at $37^{\circ} \mathrm{C}$ for $48 \mathrm{~h}$. The slides were deparafinized in Histochoice tissue fixative (Sigma, H2904) for $10 \mathrm{~min}$, washed in butanol, and passed through a descending alcohol series.

For whole-mount and sections, samples were washed with PBS, and incubated with 3\% BSA for 30 min to block nonspecific binding. Samples were then incubated overnight at $4{ }^{\circ} \mathrm{C}$ with a NKA $\alpha 1$ of human origin [diluted 1:50; NKA $\alpha(\mathrm{H}-300)$, Santa Cruz Biotechnology, Santa Cruz, CA], which specifically recognizes the alpha subunit of the cephalopod NKA (see Ref. 30) and a polyclonal antibody raised 
in rabbit against a synthetic peptide corresponding to a $\mathrm{COOH}$ terminal region of tilapia NHE3 (diluted 1:100; generously provided by Dr. Toyoji Kaneko). After being rinsed with PBS for $20 \mathrm{~min}$, samples were further incubated in goat anti-rabbit IgG Alexa-Fluor 488 and 568 (dilution 1:100). To allow double-color immunofluorescence staining for NKA and NHE3, one of the polyclonal antibodies (e.g., NKA) was directly labeled with Alexa Fluor dyes using Zenon antibody labeling kits (Molecular Probes, Eugene, OR). After rinsing in PBS $(3 \times 5 \mathrm{~min})$, samples were examined with a fluorescent microscope (Zeiss Imager $1 \mathrm{M}$ ) with an appropriate filter set and a phase-contrast device.

Immunoblotting. For immunoblotting, $10 \mu \mathrm{l}$ of crude extracts from the respective tissues were used. Proteins were fractionated by SDSPAGE on $10 \%$ polyacrylamide gels, according to Lämmli (37), and transferred to PVDF membranes (Millipore), using a tank blotting system (Bio-Rad). Blots were preincubated for $1 \mathrm{~h}$ at room temperature in TBS-Tween buffer [TBS-T, $50 \mathrm{mM}$ Tris. $\mathrm{HCl}, \mathrm{pH} 7.4,0.9 \%$ (wt/vol) $\mathrm{NaCl}, 0.1 \%$ (vol/vol) Tween 20] containing 5\% (wt/vol) nonfat skimmed milk powder. Blots were incubated with the primary antibody (see previous section) diluted $1: 250$ at $4^{\circ} \mathrm{C}$ overnight. After washing with TBS-T, blots were incubated for $2 \mathrm{~h}$ with horseradish-conjugated goat anti-rabbit IgG antibody (diluted 1:5,000, at room temperature; Jackson Laboratories, West Grove, PA). The blots were developed with 5-bromo-4-chloro-3-indolylphosphate/ nitro-blue tetrazolium.

Vital dye staining. Embryos were carefully removed from the egg capsule and incubated in the perivitelline fluid (PVF) for vital dye staining. Na-dependent fluorescent reagent, Sodium Green tetra-acetate cell permeant (Invitrogen, Carlsbad, CA), was diluted in DMSO to a $10-\mathrm{mM}$ stock solution. Sodium Green is well established as a reagent to detect intracellular $\mathrm{Na}^{+}$accumulation $(14,69)$. Life stages 26-28 embryos were incubated in $10 \mu \mathrm{M}$ Sodium Green diluted in 0.2 $\mu \mathrm{m}$ filtered natural seawater for $40 \mathrm{~min}$.

Mitochondrial-staining reagent, MitoTracker Green FM (Invitrogen, M-7514), was used to detect mitochondria-rich cells on the skin of cephalopod embryos. For staining with MitoTracker, embryos were incubated for $30 \mathrm{~min}$ in $500 \mathrm{nM}$ MitoTracker. In double stains of Sodium Green and MitoTracker with concavalin A (ConA; a lectin protein capable of selectively binding $\alpha$-mannopyranosyl and $\alpha$-glucopyranosyl residues), embryos were first incubated in $10 \mu \mathrm{M}$ Sodium Green or $500 \mathrm{nM}$ MitoTracker for $40 \mathrm{~min}$ and subsequently transferred to a solution of $50 \mu \mathrm{g} / \mathrm{ml}$ of Alexa Fluor 594-conjugated ConA (Invitrogen) diluted in filtered seawater, in which they were incubated for another $40 \mathrm{~min}$.

Embryos were washed briefly with filtered seawater and anesthetized with $0.2-0.5 \% \mathrm{MgCl}_{2}$, which is a widely used nontoxic anesthetic for cephalopods (44). Pictures were taken using a fluorescent microscope (Imager M1, Zeiss). Sodium Green was excited by a mercury vapor light source through an excitation filter with maximum transmission at $485 \mathrm{~nm}$ and a $20-\mathrm{nm}$ bandwidth. The fluorescence was collected using a 515- to 565-nm bandpass emission filter. We confirmed that the anesthetic $\mathrm{MgCl}_{2}$ did not affect illumination of Sodium Green and additionally performed negative controls with untreated embryos. Single focused images were created from a series of partially focused images using the Helicon Focus software (Helicon, Kharkov, Ukraine).

Scanning electron microscopy. For scanning electron microscopy observations, living squid embryos were removed from the egg capsule and immediately fixed in $4 \%$ paraformaldehyde with $5 \%$ glutaraldehyde for $10 \mathrm{~h}$. Afterward, the samples were transferred to a $0.1 \mathrm{M}$ sodium cacodylate buffer solution and washed three times. The membrane fixation was performed with $1 \% \mathrm{OsO}_{4}$ in $0.1 \mathrm{M} \mathrm{PB}$ for 30 min under a fume hood. After fixation, the samples were washed in $0.1 \mathrm{M}$ sodium cacodylate buffer. For dehydration, the samples passed an ascending concentration of ethanol $(50 \%, 70 \%, 80 \%, 95 \%$, and $100 \%$ ). The samples were dried in a critical point drier (Hitachi HCP-2 CPD), were gold coated (Cressington Sputter Coater 108), and were observed using a scanning electron microscope (Environmental Scanning Electron Microscope, FEI Quanta 200).

Scanning ion-selective electrode technique. The scanning ionselective electrode technique (SIET) was used to measure $\mathrm{H}^{+}$fluxes at the body surface of $S$. lessoniana embryos (stage 28). Glass capillary tubes (no. TW 150-4; World Precision Instruments, Sarasota, FL) were pulled on a Sutter P-97 Flaming Brown pipette puller (Sutter Instruments, San Rafael, CA) into micropipettes with tip diameters of 3-4 $\mu \mathrm{m}$. These were then baked at $120^{\circ} \mathrm{C}$ overnight and vaporsilanized with dimethyl chlorosilane (Sigma-Aldrich) for $30 \mathrm{~min}$. The micropipettes were backfilled with a 1-cm column of electrolytes and front-loaded with a 20 - to $30-\mu \mathrm{m}$ column of liquid ion exchanger cocktail (Sigma-Aldrich) to create an ion-selective microelectrode (probe). The following ionophore cocktail (and electrolytes) was used: $\mathrm{H}^{+}$ionophore I cocktail B $\left(40 \mathrm{mM} \mathrm{KH} \mathrm{PO}_{4}\right.$ and $15 \mathrm{mM} \mathrm{K}_{2} \mathrm{HPO}_{4}$; $\mathrm{pH}$ 7). The details of the system were described previously (40). To calibrate the ion-selective probe, the Nernstian property of each microelectrode was measured by placing the microelectrode in a

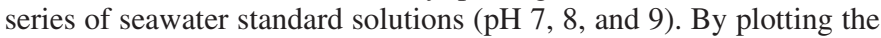
voltage output of the probe against $\log \left[\mathrm{H}^{+}\right]$values, a linear regression yielded a Nernstian slope of $58.6 \pm 0.6(n=10)$ for $\mathrm{H}^{+}$.

Measurement of surface $\mathrm{H}^{+}$gradients. SIET was performed at room temperature $\left(26-28^{\circ} \mathrm{C}\right)$ in a small plastic recording chamber filled with $2 \mathrm{ml}$ filtered natural sea water $(\mathrm{pH} \mathrm{8.1)}$. Before the measurement, embryos were positioned in the center of the chamber with their dorsal side contacting the base of the chamber. The ion-selective probe was moved to the target position (10-20 $\mu \mathrm{m}$ away from the larval surface) to record the ionic activities; then the probe was moved away $(10 \mathrm{~mm})$ to record the background. The duration to measure one individual took around $10 \mathrm{~min}$ with 1-2 min for each reference and measuring point. After the recording, squid embryos were still alive for several hours and had normal mantle and heart contractions. In this study, a proton concentration gradient was determined by measuring $\mathrm{H}^{+}$gradients between the targets (at the surface of larval skin) and background.

The specific NHE inhibitor 5-ethylisopropyl amiloride (EIPA) (Sigma-Aldrich) was used to examine the inhibitory effects on proton secretion at the skin surface in the head region of $S$. lessoniana embryos. EIPA was dissolved in DMSO (Sigma-Aldrich) and added to natural seawater at a final concentration of 1 and $10 \mu \mathrm{M}$. The final concentration of DMSO in working solution was $0.1 \%$ and did not affect proton transport (see Fig. 6B).

Embryos were bathed in this inhibitor solution for $10 \mathrm{~min}$ and then transferred to the recording chamber. All seawater fluids used for experimentation were fully air saturated.

\section{RESULTS}

Ontogeny-dependent activity of NKA in cephalopod embryos. During embryonic development of $S$. officinalis ATPase activities in whole animal homogenates reached detectable levels in stages 26 and 27 embryos with a body mass of 30 to $60 \mathrm{mg}_{\mathrm{FM}}$ (Fig. 1A). Later, in stage 28 to 29 embryos, enzyme activities increase rapidly, until activities stabilize toward hatching (200-400 $\mathrm{mg}_{\mathrm{FM}}$ ). After hatching, animal body masses increase, but specific NKA and total ATPase activity remain constant. Both, total ATPases and NKA increase in a similar fashion, following a sigmoidal curve matching the increased concentration of this enzyme detected via immunohistochemical methods. During the final phase of development from stage 27 until hatching, embryos increase their body mass by $\sim 400 \%$ (from 100 to $400 \mathrm{mg}$ wet mass).

Ontogeny of gill and intestine NKA immunoreactivity. In S. officinalis stage 24 embryos [mental length $(\mathrm{ML})=2-3 \mathrm{~mm}$ ], the gills were $60-80 \mu \mathrm{m}$ in length and not yet fully differen- 
A

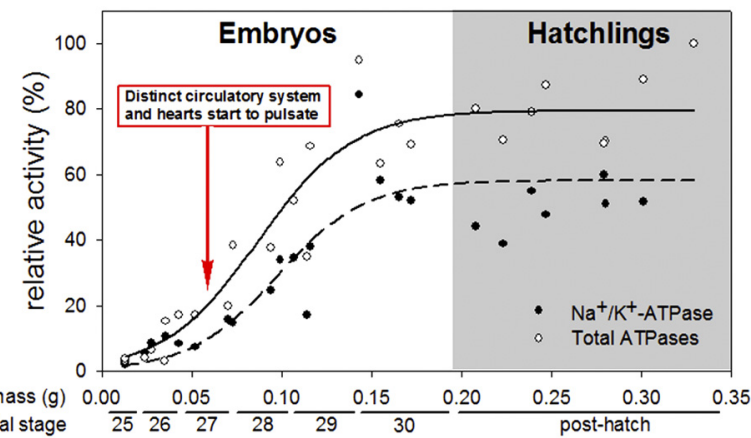

B

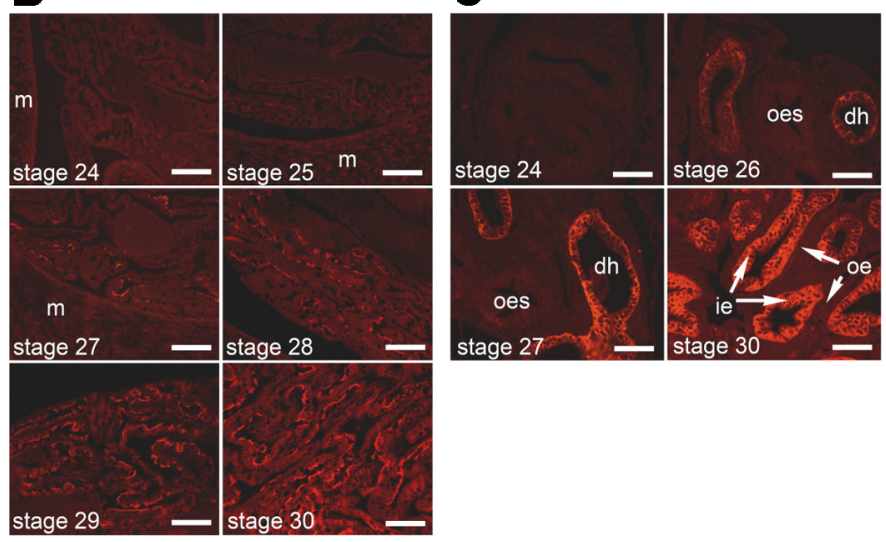

Fig. 1. A: ontogeny-dependent relative activity of total ATPases and $\mathrm{Na}^{+} / \mathrm{K}^{+}$ ATPase in whole animal homogenates of Sepia officinalis plotted against the animal mass ( $\mathrm{g}_{\mathrm{FM}}$ ) and stage [according to Lemaire (39)]. The increase in maximum activity was fitted by sigmoidal curves for both total ATPase (solid line; $R=0.8704$ ) and $\mathrm{Na}^{+} / \mathrm{K}^{+}$-ATPase (dashed line; $R=0.9493$ ). At stage 27 , all of the major vessels of the arterial and venous system become distinct, and the auxiliary hearts are functional. In earlier stages (20-25), only primitive vena cava vessels and hemal spaces are found in the yolk and head region. $B$ : cross sections of the cuttlefish gill at stages $24,25,27,28,29$, and 30 [according to Lemaire (39)] showing first occurrence of $\mathrm{Na}^{+} / \mathrm{K}^{+}$-ATPase in gill tissues at stage 26 and progressively increasing with the development of the gill epithelium. $C$ : cross sections of the cuttlefish pancreatic appendages (PA) at stages 24, 26, 27, and 30, showing first occurrence of $\mathrm{Na}^{+}-\mathrm{K}^{+}$-ATPase in the inner epithelium (ie) of PA tissues at stage 26 and progressively increasing with the differentiation of the PAs. $\mathrm{m}$, mantle; dh, ductus hepatopancreas; oes, oesophagus; outer epithelium, oe.

tiated, missing the 2nd- and 3rd-order lamellae (Fig. 1B). During ontogeny, the gills progressively differentiate with 1stto 3rd-order vessels and lamellae visible in stage 30 embryos at a total gill length of $\sim 900 \mu \mathrm{m}$ and ML of $8-10 \mathrm{~mm}$ (Fig. $1 B)$. NKA is not detectable in gill tissues until stage 24 embryos, whereas in later stages (25 to 30 ) this enzyme begins to be progressively more detectable in the developing gill (Fig. $2 B$ ). The increase of NKA staining correlates with the differentiation of gill lamellae toward hatching.

The pancreatic appendages (PA) in S. officinalis are part of the digestive tract and consist of alveolar/tubular shaped protrusions of the ductus hepatopancreas within the dorsal renal sac (Fig. 1C). In stage 30 embryos, these protrusions had a diameter ranging from 15 to $25 \mu \mathrm{m}$ and from 100 to $200 \mu \mathrm{m}$ $(\mathrm{ML}=6-7 \mathrm{~mm})$. These appendages consist of an inner and an outer epithelium. The cells of both epithelia line a blood sinus with their basal lamina. Generally, the cells of the inner epithelium are two- to three-fold higher than those from the outer epithelium (Fig. 1C). In late-stage embryos (stages 2730 ), the cells of the inner epithelium can be characterized by a very strong NKA immunoreactivity, whereas the outer epithelium shows little immunoreactivity in its membranes. In stage 23 embryos, no or only very weak NKA immunoreactivity is detectable in the PA. With the differentiation of this organ during embryonic development, the occurrence of NKA increases toward hatching in a similar manner, as described for the gill epithelium (Fig. 1C).

Whole-mount in situ hybridization. Whole-mount in situ hybridization with $S$. officinalis embryos revealed expression of NKA in the head region and on the yolk epithelium. In stage 27 embryos, reaction precipitates were found in several areas

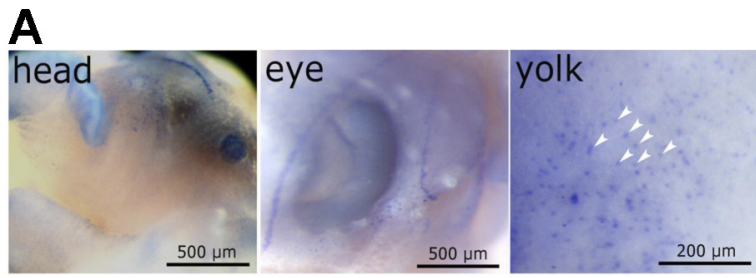

B
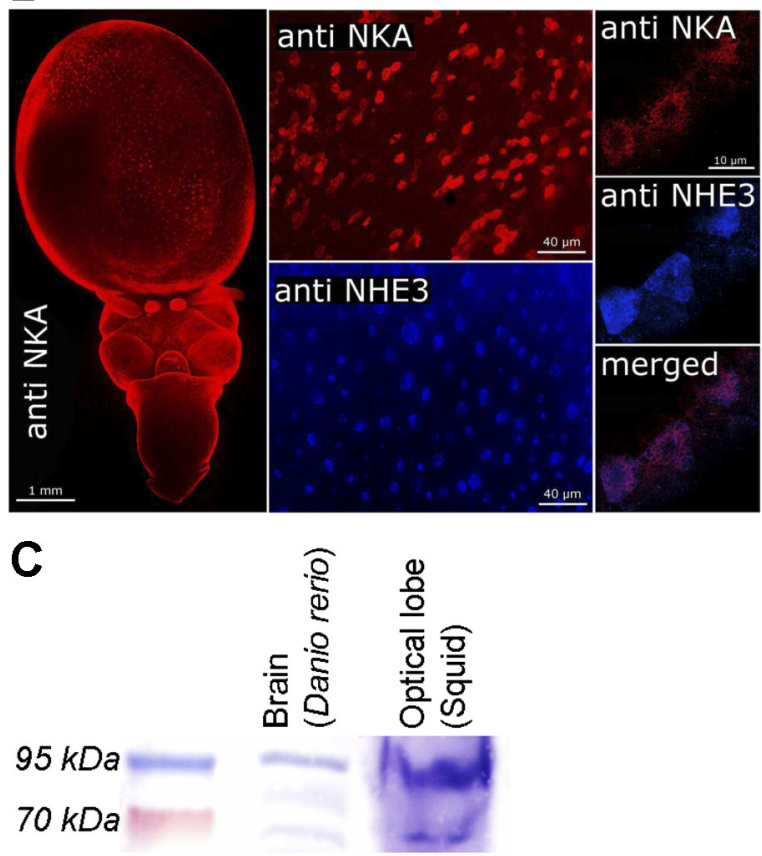

Fig. 2. A: Whole-mount in situ hybridization of $\mathrm{Na}^{+}-\mathrm{K}^{+}$-ATPase (NKA) on $S$ officinalis embryos. In stage 27 embryos, single NKA-expressing cells are scattered on the ventral side of the head. Additionally, cells of the oval shaped olfactory organ are rich in NKA mRNA. Dorsal view of the head of a $S$. officinalis embryo, showing sensory cells of the head line system and scattered cells below the eye with high NKA expression. Expression of NKA on the yolk epithelium. Note the "salt-and-pepper" pattern of these ionocytes. Some of the cells, which are most likely ionocytes, are marked with arrows. B: immunohistological localization of $\mathrm{Na}^{+}-\mathrm{K}^{+}$-ATPase and NHE3-rich cells on the yolk sac epithelium of the squid Sepioteuthis lessoniana (first and second panel) and cuttlefish S. officinalis (stage 27 embryo, merged image). In both species, ionocytes are scattered in a salt-and-pepper pattern over the entire yolk epithelium. Higher-magnification images of several ionocytes with positive NKA and $\mathrm{Na}^{+} / \mathrm{H}^{+}$-exchanger (NHE3) immunoreactivity on the ventral side of the yolk with densities of $40-60$ cells per $100 \mu \mathrm{m}^{2}$. NKA-rich cells are $\sim 10$ $\mu \mathrm{m}$ in diameter and are colocalized with NHE-rich cells. $C$ : Western blot analysis of NHE3 in brain tissues of zebrafish (Danio rerio), optical lobe of squid (S. lessoniana), demonstrating immunoreactivity of the NHE3 antibody with a $95-\mathrm{kDa}$ protein. 
Fig. 3. Localization of NKA, NHE3, and the glycoprotein concavilin A (ConA) in epidermal cells on the skin of S. lessoniana embryos (stages 26 and 27). Epidermal cells that are positively labeled by ConA are not colocalized with NKA antibody (NaR) cells (left). These $\mathrm{NaR}$ cells are not colocalized with cells that exhibit positive NHE3 immunoreactivity and ConA labeling (middle left). Inset: S. lessoniana embryo with a rectangle indicating the area observed for immunostaining and vital dye staining. ConA-labeled cells on the skin of embryos are rich in mitochondria and sodium. Stainings with the cell-permeant Sodium Green vital dye demonstrates that ConA-labeled cells accumulate sodium (middle right). In addition to epidermal ionocytes, sensory cells (sc), which belong to the head-line organ of cephalopods, are also rich in mitochondria (indicated by arrows) (right). These sensory cells are not positively labeled by ConA.
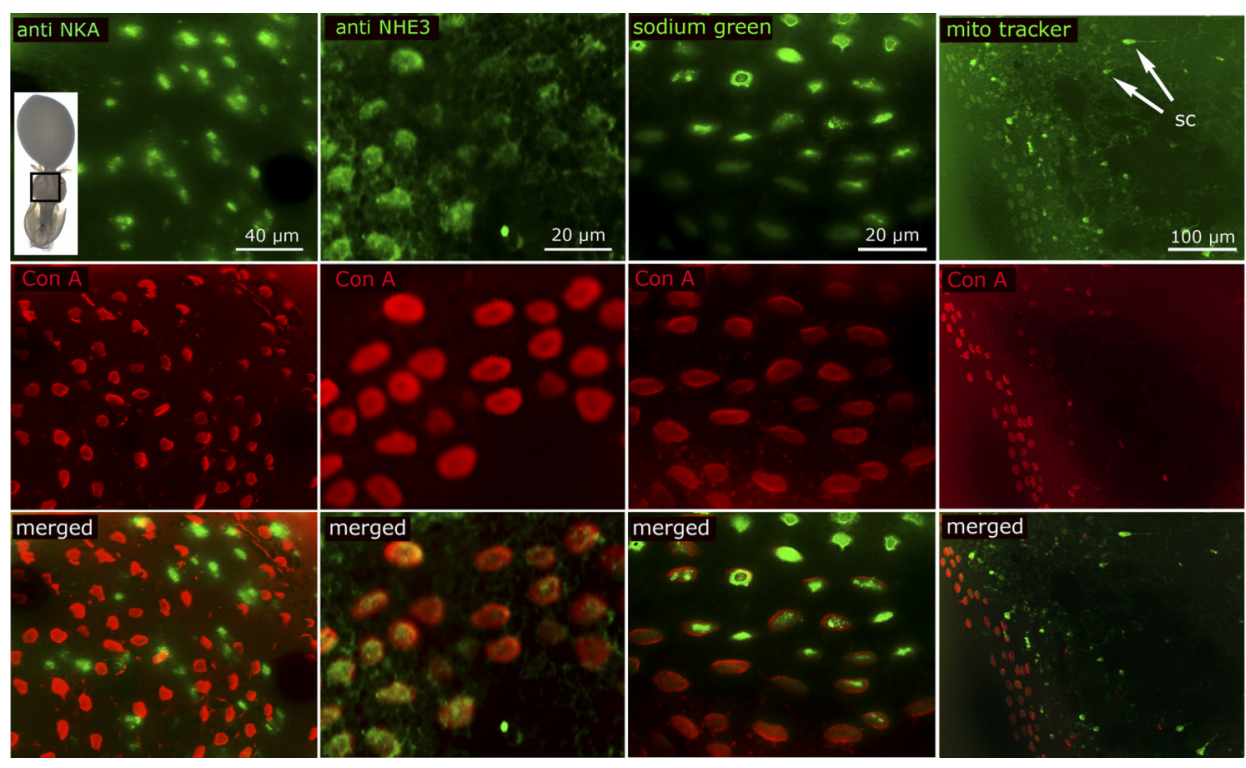

of the head, with highest densities below the eye, and on the ventral side of the head (Fig. 2A). Strong NKA expression was observed in sensory cells of the olfactory organ, forming an oval shape on the embryo's cheeks (Fig. 2A). In addition to sensory cells of the olfactory organ, sensory cells of the head-line organ exhibited clearly visible NKA expression. These sensory cells are forming longitudinal lines on the head of late-stage embryos and belong to the head line system described for some decapod cephalopods (2, 6) (Fig. 2A). Finally, single oval-shaped cells scattered on the yolk sac epithelium showed expression of NKA in these late-stage cuttlefish embryos (Fig. 2A).

Characterization and morphology of ionocytes on the yolk epithelium and skin. Whole-mount immunohistochemical analysis demonstrates that cells that are scattered on the yolk sac epithelium of cephalopod (squid and cuttlefish) embryos show a positive NKA immunoreactivity (Fig. $2 B$ ). These NKA-rich cells (NaRs) are $\sim 10 \mu \mathrm{m}$ in diameter and occur in densities of 40-60 cells per $100 \mu \mathrm{m}^{2}$. Double staining of NKA and NHE3 demonstrates that NHE3 is colocalized with NaRs on the yolk sac epithelium (Fig. 2B). Furthermore, high-magnification images show that the distribution of NKA is meshlike, whereas NHE3 is distributed equally in membranes of NaRs. Western blot analysis demonstrates that the NHE3 antibody used in this study recognizes a $95-\mathrm{kDa}$ protein, which is in the size range reported for NHE3 proteins from other species (Fig. 2C). The epitope that is recognized by the tilapia antibody used shares about $78 \%$ sequence identity with the ortholog of S. lessoniana (data not shown).

Besides the yolk epithelium, positive NKA immunoreactivity was also observed in single cells scattered on the mantle and head of squid and cuttlefish embryos (Fig. 3). Double staining with ConA revealed that $\mathrm{NaR}$ cells are not colocalized with ConAlabeled cells. Instead ConA-labeled cells on the entire skin of squid embryos were characterized by high $\mathrm{Na}^{+} / \mathrm{H}^{+}$exchanger (NHE3) immunoreactivity and sodium accumulation (Fig. 3). We termed these cells sodium-rich cells (SRCs). Highest densities of SRCs were found on the lateral side of the head, arms, and close to the olfactory organ (Fig. $4, A-C$ ). Furthermore, no SRCs were found on the yolk sac epithelium. Instead, small vesicles located inside large flattened epidermal cells that resemble pavement cells/accessory cells (51) of the entire yolk epithelium show positive sodium reactivity (Fig. $4 D$ ).

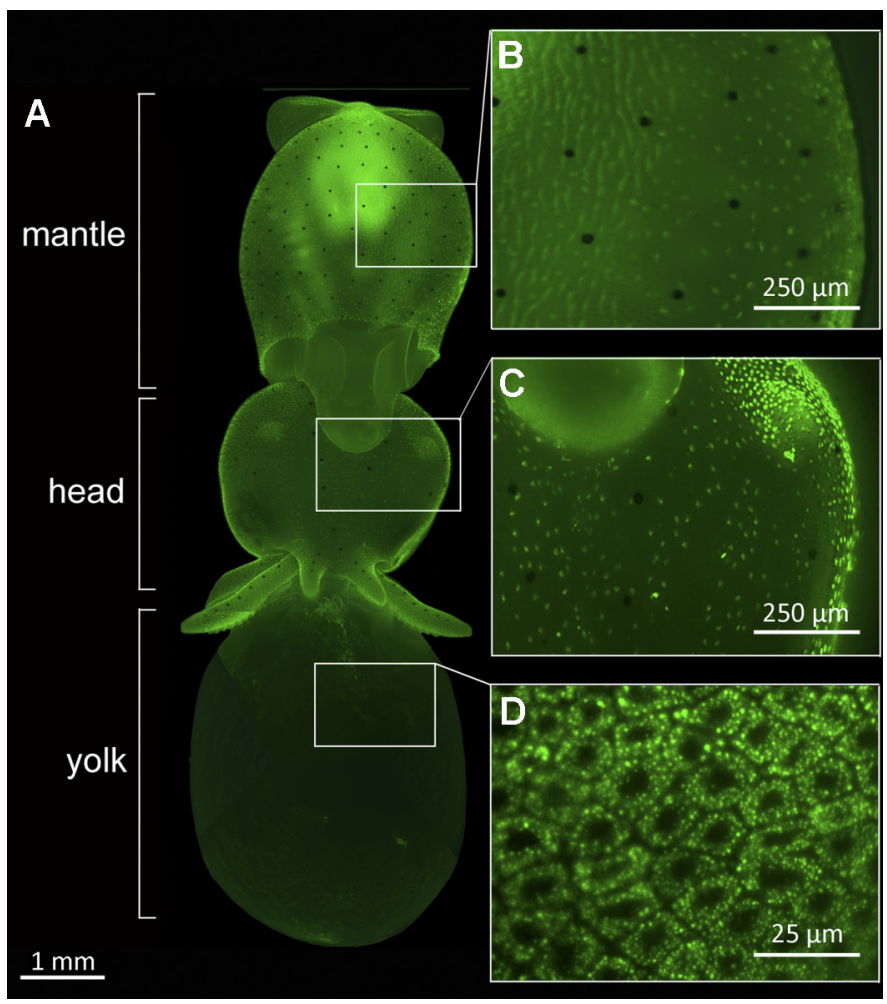

Fig. 4. A: $\mathrm{Na}^{+}$accumulation in cells on the skin and yolk of S. lessoniana embryo showing the morphology of the animal divided in mantle, head, and yolk. On the skin in the mantle and head region Sodium Green, a $\mathrm{Na}^{+}-$ dependent fluorescent reagent, predominantly stains round- to oval-shaped cells scattered on the skin surface of stage 28 embryos $(B$ and $C$ ). $C$ : higher cell densities are found on the lateral side of the head region. $D$ : high magnification of the yolk sac surface demonstrating the presence of Sodium Green signals equally distributed in epithelial cells. Note the grain-like pattern of the fluorescence signal in these cells. 

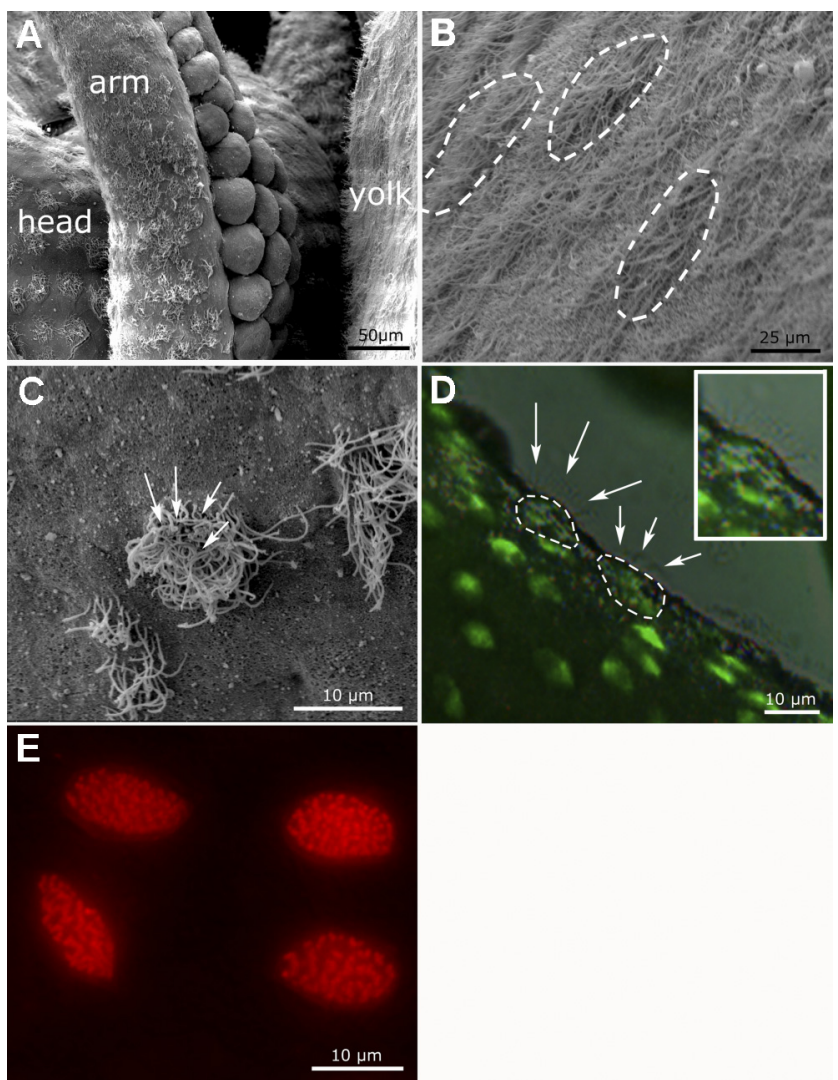

Fig. 5. Scanning electron micrographs of the skin and yolk surface of a squid embryo (stage 27). A: ciliated cells are scattered over the skin of the head and arms of the embryo. $B$ : the entire yolk is covered with ciliated cells. In contrast to the body, different types of ciliated cells with long (indicated with dashed lines) and short cilia are found on the yolk sac epithelium covering the entire surface. $C$ : a single ciliated cell located on the skin at higher magnification. Note the pore-like openings in between the cilia indicated by arrows. $D$ : furthermore, Sodium Green-labeled cells merged with a phase-contrast image demonstrate the colocalization of sodium-rich cells (surrounded with dashed lines) with ciliated cells on the skin (cilia indicated by arrows). Inset: enlarged picture of one single ciliated cell merged with the same Sodium Green-labeled cell. E: high magnification of ConA-labeled cells showing the scattered distribution of ConA labeling on the surface of cells, which support the mesh-like openings of this type of ionocyte that are very similar to those observed in zebrafish (26).

Using MitoTracker, we were able to identify two types of mitochondria-rich cells: 1) sensory cells exclusively located on the head of the embryo and 2) the already mentioned ConAlabeled SRCs (Fig. 3). By merging Sodium Green-labeled cells with a bright-field phase-contrast image, we were able to show that the sodium-rich, ConA-labeled ionocytes are ciliated cells distributed over the entire skin of the squid embryo with highest densities in the head and arm region (Fig. 5D).

Scanning electron microscopy analysis revealed the occurrence of different types of ciliated cells located on the mantle, head, and yolk of the embryo, as previously described by Arnold and Williams-Arnold (2) (Fig. 5, $A-C$ ). Moreover, high-resolution images demonstrate that underneath the cilia, these cells seem to be characterized by meshlike openings (Fig. $5 C$, indicated by arrows), which resemble ionocyte crypts described for the skin of fish larvae $(26,27)$. The presence of this fenestration on the outer surface of skin ionocytes is further supported by the pattern of ConA labeling, which consists of dots scattered over the entire surface of one iono- cyte [Fig. $5 E$; the pattern is very similar to that observed in zebrafish by Horng et al. (26), depicted in Fig. 1C].

$\mathrm{H}^{+}$gradients on the surface of skin and yolk epithelia. Using ion-selective electrodes, we determined $\left[\mathrm{H}^{+}\right]$gradients at different locations on the entire surface of squid embryos (Fig. 6A). On the yolk, smaller proton gradients were detected with a $\Delta\left[\mathrm{H}^{+}\right]$ 0.2 to $0.4 \mu \mathrm{mol}$ over the entire yolk epithelium (points 1 to 3 ). On the skin close to the eye and the head (points 4 and 5), proton secretion showed peak $\Delta\left[\mathrm{H}^{+}\right]$with up to 3 to $4 \mu \mathrm{mol}$, whereas on the mantle (point 6 ), proton $\Delta\left[\mathrm{H}^{+}\right]$decreased again down to $0.4 \mu \mathrm{mol}$. Moreover, the present work demonstrated that proton secretion on the skin surface in the head region is highly sensitive to EIPA, a specific NHE blocker (Fig. 5B). Using two concentrations of EIPA, a dose-dependent decrease to $60 \%$ and $44 \%$ was observed in the presence of $1 \mu \mathrm{M}$ and 10 $\mu \mathrm{M}$ EIPA, respectively.
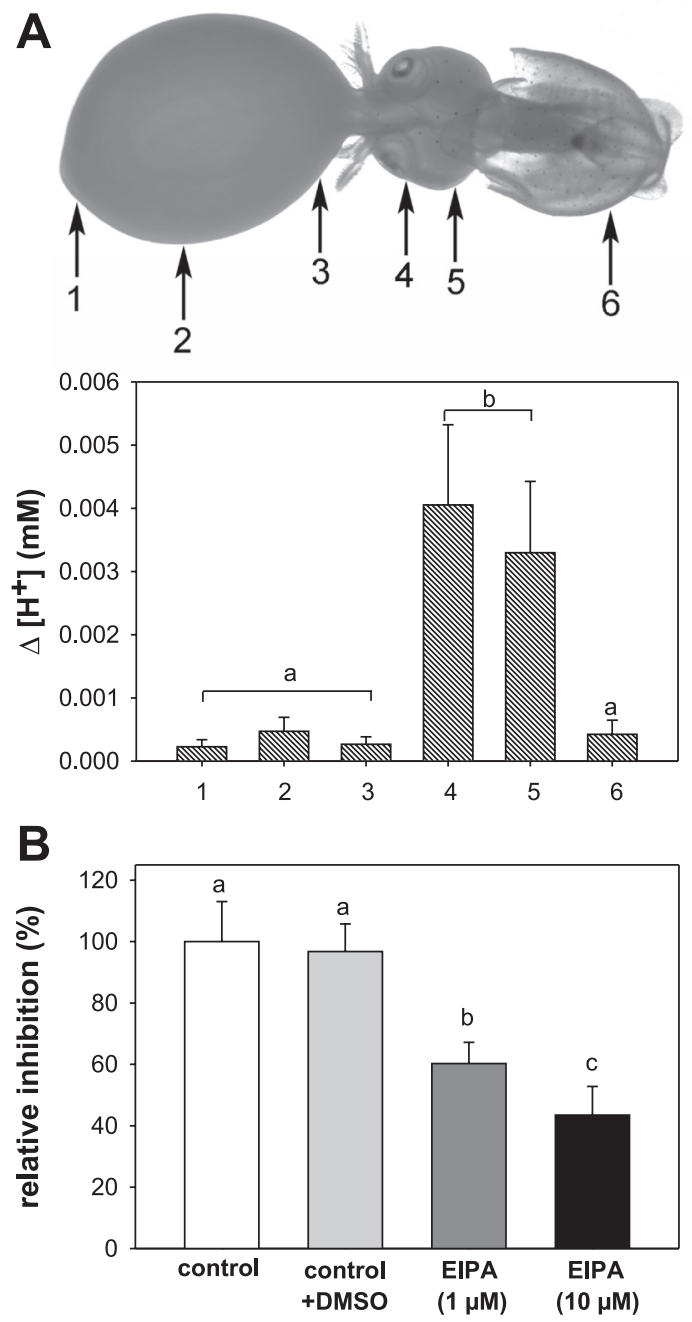

Fig. 6. $A$ : measurement of proton gradients $\left(\Delta\left[\mathrm{H}^{+}\right]\right)$on the skin and yolk epithelium of $S$. lessoniana embryos (stages 28 and 29). Ion-selective electrode technique measurements demonstrate that the entire animal, including yolk, head, and mantle has positive $\Delta\left[\mathrm{H}^{+}\right]$values with the highest levels detected in the head region (spots 4 and 5), indicating a secretion of protons. $B$ : lower $\mathrm{H}^{+}$ secretion values were recorded for the entire yolk surface. Bars represent means \pm SE; $n=8$. Inhibitory effects on proton secretion in the presence of 1 and $10 \mu \mathrm{M}$ EIPA. Bars represent means \pm SE; $n=6$. Letters denote significant differences between treatments $(P<0.02)$. 


\section{DISCUSSION}

The convergent evolution of morphological and physiological features enabling mobile cephalopods and fish to compete for similar resources in marine pelagic and bentho-pelagic habitats has been widely recognized $(46,48)$. Here, we show for the first time that such convergent development can be found in the lecithotrophic embryonic stages of decapod cephalopods; epidermal ionocytes on skin and yolk sac appear to be responsible for ionic regulation before gill epithelia become functional. Furthermore, this is the first study that shows that, in vivo, acid equivalents are secreted by the yolk and skin integument of a marine invertebrate.

Marine animals that exhibit an oviparous mode of development, such as most fish and cephalopods, are exposed to very high $\mathrm{PCO}_{2}$ values during their embryonic development. This is mainly due to the fact that egg capsules of most molluscs, amphibians, and fish were shown to act as a diffusion barrier for respiratory $\mathrm{O}_{2}$ and $\mathrm{CO}_{2}(11-13,16,23)$. To maintain a sufficiently high flux of oxygen in and carbon dioxide out of the egg capsule, hypoxic hypercapnic conditions develop inside the egg fluid of cephalopod (and, probably, fish) eggs, particularly toward the end of embryonic development, when metabolic rates are highest (23). A recent study demonstrated that increases in environmental $\mathrm{PCO}_{2}$ are additive to those of the PVF of cephalopod eggs, leading to $\mathrm{PCO}_{2}$ values as high as $0.6 \mathrm{kPa}$ at an environmental $\mathrm{PCO}_{2}$ of $0.35 \mathrm{kPa}$ (29). Such high environmental $\mathrm{PCO}_{2}$ values can be encountered by cephalopod and fish egg masses in seasonally hypoxic coastal habitats (61). Hypoxic hypercapnic conditions constitute a major abiotic stress to the developing embryo in terms of acid-base disturbances, as they also lead to an increased $\mathrm{PCO}_{2}$ of body fluids to maintain the diffusive flux of $\mathrm{CO}_{2}$ out of the animal (43). As late-stage embryonic fish and cephalopods rely on hemoglobin or hemocyanin-driven oxygen transport as well, it can be assumed that these embryonic stages require an efficient acidbase regulatory machinery to protect their $\mathrm{pH}$-sensitive respiratory pigments from hypercapnia-induced $\mathrm{pH}$ reductions. To accomplish this, both cephalopods and fish have to manipulate their extracellular carbonate system: elevated blood $\left[\mathrm{HCO}_{3}^{-}\right]$at the high surrounding $\mathrm{PCO}_{2}$ values guarantee $\mathrm{pH}$ values suitable for protein-mediated gas transport $(24,38)$. However, maintenance of blood acid-base status requires continuous net $\mathrm{H}^{+}$ excretion, thus, ion regulatory effort.

During larval development of fish and cephalopods, rudimentary gill structures progressively develop and become complete when the organism has reached an adult-type morphology $(1,32,49,56)$. Prior to the gills, it has been demonstrated that the fish integument is responsible for respiratory gas exchange (66), and ionocytes on the yolk epithelium are involved in osmo- and acid-base regulation $(22,34,35,40)$. During cephalopod organogenesis, thus before systemic and branchial hearts are developed, muscle cells on the yolk sac are responsible for convective circulation of hemolymph: peristaltic movements propel hemolymph around the yolk syncytium and into the extensive lacunar blood system of the embryo. Prior to differentiation of blood vessels, these blood sinuses are occupying large volumes of the embryonic body, particularly in the (metabolically) active head region (see Refs. 62 and 63). Thus, the integument must be the main respiratory organ in cephalopods prior to gill development, and well-perfused and met- abolically active regions, such as the head and the "yolk sac heart" are prime candidate tissues for the localization of ionocytes, and our study provides evidence to support this hypothesis. The characterization of epidermal ionocytes, predominantly located on the skin in the head region of cephalopod embryos, demonstrated that one group of cells, which were recognized by ConA and MitoTracker, also expresses NHE-3. These SRCs are apparently responsible for sodium uptake. Further, our microelectrode measurements demonstrated that these cells also mediate proton excretion. Another group of epithelial cells is exclusively labeled by the NKA antibody (NaR cells). It is unclear what the function is of these cells. In zebrafish (Danio rerio) embryos, at least three types of epidermal ionocytes were identified and classified into $\mathrm{Na}^{+} / \mathrm{Cl}^{-}$ cotransporter-rich cells, proton pump-rich (HR) cells, and NaR (for a review, see Ref. 34). The HR cells were further characterized by high-sodium accumulation, which was significantly blocked in the presence of 10 and $100 \mu \mathrm{M}$ EIPA, a NHE inhibitor, supporting the role of apical NHE3 in sodium uptake (14). Interestingly, epidermal ionocytes located in the head region of S. lessoniana embryos share many parallel features to fish HR cells, such as high sodium concentrations, high mitochondrial densities, NHE3 protein, but no detectable NKA immunoreactivity. However, ionocytes located on the yolk sac epithelium are rich in NKA and NHE3. Another group of ConA-positive cells, which are similar in appearance to pavement cells (Supplemental Fig. S1) surprisingly can absorb sodium from the ambient medium.

While the skin, especially in the head and arm region, is characterized by a strong outward directed proton flux, the cephalopod yolk epithelium is characterized by a comparatively lower proton efflux. However, it needs to be noted that this organ exhibits a relatively large surface area compared with the head and the mantle, thus the total contribution to proton excretion might be large. Especially in earlier stages, with a low body surface-to-yolk surface ratio, the yolk can be considered an even more significant site for proton secretion, and thus, $\mathrm{pH}$ regulation.

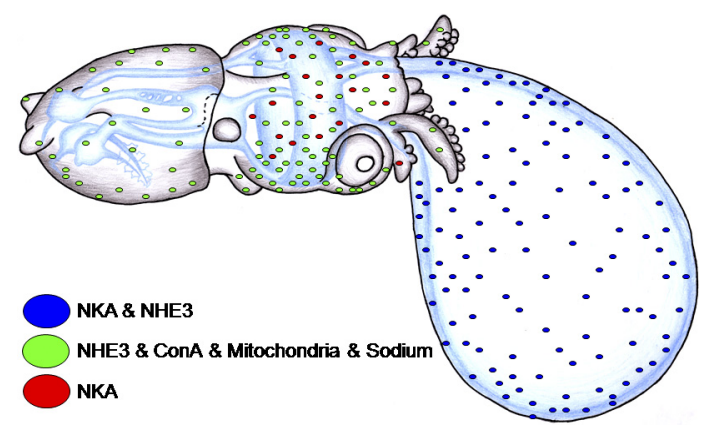

Fig. 7. There are at least three types of epidermal ionocytes in cephalopod embryos, located on skin and yolk epithelium. The highest densities of ionocytes are found in areas with large subcutaneous blood spaces, such as the head and yolk. One type of ionocyte on the yolk epithelium is characterized by the occurrence of NKA, probably located in basolateral membranes and positive NHE3 immunoreactivity. Furthermore, the cells of this epithelium are characterized by high concentrations of $\mathrm{Na}^{+}$localized in intracellular vesicles. The skin of cephalopod embryos exhibits at least one other type of ionocyte. These positively ConA-labeled cells are rich in mitochondria and show high intracellular sodium accumulation. Additionally, these cells show positive NHE3 immunoreactivity, but are not colocalized with NKA-rich cells. Electrophysiological data suggest that ionocytes located on the skin are involved in active acid (probably also $\mathrm{CO}_{2}$ ) secretion. 
In embryos of teleosts, the yolk epithelium was also identified as a major site of ionic regulation, indicated by the presence of four different subtypes of ionocytes equipped with transporters relevant for ion and acid-base regulation (see reviews by Refs. 33 and 34). Although V-type $\mathrm{H}^{+}$-ATPases were identified to be key players of apical acid secretion pathways in freshwater fish $(15,33,50)$, new models for $\mathrm{pH}$ regulation are recently emerging for the marine environment (70). Immunohistochemical and electrophysiological methods demonstrated that epithelial ionocytes of Oryzias latipes larvae, which are rich in NHE3 and $\mathrm{Rh}$ glycoprotein-C, are actively involved in the secretion of protons (70). This involvement of NHE-like proteins in the secretion of protons and, thus, acid-base regulation is similar to their role in the renal proximal tubule of the mammalian kidney. Here, the majority of protons are excreted into the lumen of the tubule via different NHE isoforms, including NHE2, NHE3, and NHE8 located in the brush-border microvilli of the proximal tubule $(19,64,65)$.

We summarized the vital dye and immunocytochemical stainings of cephalopod embryonic stages in Fig. 7, to illustrate the presence of ionocytes predominantly in the well-perfused regions such as yolk and head. In this summary, mitochondriarich cells located on the skin of the embryo exhibit positive NHE3 immunoreactivity and high cytosolic sodium accumulation. Furthermore, the microenvironment in this area is characterized by increased EIPA-sensitive proton secretion, suggesting that also in cephalopod embryos, NHE proteins are major players of proton secretion. The involvement of NHE to secrete acid equivalents in the marine environment can be regarded thermodynamically favorable due to high external $\left[\mathrm{Na}^{+}\right](\sim 460 \mathrm{mM})$ compared with low intracellular $\left[\mathrm{Na}^{+}\right]$ $(\sim 30 \mathrm{mM}$ in $S$. officinalis), which provide a natural driving force $(52,53)$. In the freshwater environment, where sodium gradients are opposed to those in marine habitats, V-type $\mathrm{H}^{+}$-ATPases were proposed to be responsible for the majority of $\mathrm{H}^{+}$secretion (40).

Intriguingly, the present work demonstrates that epidermal ionocytes of cephalopod embryos are ciliated. The primary role of these ciliated cells is to create a convective current inside the PVF to prevent the formation of gradients of dissolved respiratory gases and excretory products within PVF prior to full development of the ventilatory organs, the mantle and collar flap musculature $(2,3,17)$. To our best knowledge, this is the first report that shows that ciliated epidermal cells are both involved in water transport and are equipped with high concentrations of ion-transporting molecules capable of proton secretion.

Once the embryonic hearts are functional and the blood vessels are developed, the "yolk sac heart" loses its contractile properties, and the cilia on the yolk sac shorten $(2,62,63)$. Our gill NKA activity measurements (Fig. 1) suggest that in stage 30, S. officinalis, hatchling-like NKA activities have been reached. It can be assumed that at this point in development, gill epithelia are able to fully support the acid-base regulatory needs of the embryo. In a previous study, we could demonstrate high-mRNA levels of acid-base-relevant genes such as $\mathrm{Na}^{+} / \mathrm{HCO}_{3}^{-}$-cotransporter (NBC), CA2, and sodium pump (NKA) in gill tissues of late embryos (stages 29 and 30) and hatchlings of the cuttlefish S. officinalis (29). It has been demonstrated that during stage 30 , premature hatching of viable animals can be induced by means of sensory stimulation or through adverse environmental conditions (Ref. 5 and unpublished observation). In such situations, the entire remainder of the outer yolk sac is abruptly shed, and the animal leaves the egg capsule.

\section{Perspectives and Significance}

The initial characterization of epidermal ionocytes on cephalopod yolk and skin in the present work provided evidence that these specialized cells are actively involved in ion and acid-base regulation, and furthermore, they exhibit a set of specific enzymes that probably enable extracellular $\mathrm{pH}$ homeostasis in the developing embryo. These observations also suggest that in lecithotrophic embryonic stages of decapod cephalopods and fish, a convergent ontogenetic pattern of ionregulatory function can be observed. Moreover, the different types of ionocytes identified in cephalopod embryos are involved in sodium and proton exchange and are equipped with NKA and NHE3. Further investigations are necessary to identify and characterize the full set of acid-base relevant proteins of these ionocytes. NHE and Rh proteins may be important candidate genes, as they were proposed to have a dual NH3/ $\mathrm{CO}_{2}$ transport function $(45,59,60)$, and thus, they may represent another group of key transporters in embryonic acid-base regulation and gas exchange.

Moreover, direct in vivo electrophysiological measurements demonstrate that acid equivalents are secreted by the yolk and skin integument of a marine organism and that NHE may be a major player in this process. Future investigations will apply ion-selective electrode techniques on single ionocytes in combination with specific inhibitors to demonstrate the importance of NHE proteins for proton secretion in embryonic stages of cephalopods and fish, and, thus utilize a comparative approach to derive fundamental mechanisms of acid-base regulation in these high-metabolism, ectothermic marine taxa.

\section{ACKNOWLEDGMENTS}

We are very grateful to J. P. Robin and A. Fink who helped to obtain the cuttlefish eggs.

\section{GRANTS}

This study was partly funded by a Deutsche Forschungsgemeinschaft Excellence Cluster Future Ocean Grant awarded to F. Meizner and a Deutscher Akademischer Austausch Dienst/National Science Council Project-Based Personnel Exchange Programme Grant (project ID 50128946) awarded to F. Meitzner and P-P. Hwang. This work is a contribution to the German Ministry of Education and Research-funded project "BiologicalImpacts of Ocean ACIDification" subproject 3.1.3 awarded to F. Meitzner.

\section{REFERENCES}

1. Arnold JM. Normal embryonic stages of the squid, Loligo pealii (Lesueur). Biol Bull 128: 24-32, 1965.

2. Arnold JM, Williams-Arnold LD. Development of the ciliature pattern on the embryo of the squid Loligo pealei: a scanning electron microscope study. Biol Bull 159: 102-116, 1980.

3. Bone Q, Brown E, Travers G. On the respiratory flow in the cuttlefish Sepia officinalis. J Exp Biol 194: 153-165, 1994.

4. Boron WF. Regulation of intracellular pH. Adv Physiol Educ 28: 160179, 2004.

5. Bouchaud O, Daguzan J. Etude expérimentale de l'ínfluence de la témperature sur le déroulement du développement embryonaire de la Seiche Sepia officinalis L. (Cephalopode, Sepioidae). Cah Biol Mar 31: 131-145, 1990.

6. Budelmann BU, Schipp R, von Boletzky S. Cephalopoda. In: Microscopic Anatomy of Invertebrates, edited by Harrison FW and Kohn AJ. New-York: Wiley-Liss, 1997. 
7. Charmantier G, Charmantier-Daures M. Ontogeny of osmoregulation in crustaceans: The embryonic phase. Am Zool 41: 1078-1089, 2001.

8. Charmantier G, Haond C, Lignot JH, Charmantier-Daures M. Ecophysiological adaptation to salinity throughout a life cycle: A review in homarid lobsters. J Exp Biol 204: 967-977, 2001.

9. Cieluch U, Charmantier G, Grousset E, Charmantier-Daures M, Anger K. Osmoregulation, immunolocalization of $\mathrm{Na}^{+} / \mathrm{K}^{+}$-ATPase, and ultrastructure of branchial epithelia in the developing brown shrimp, Crangon crangon (Decapoda, Caridea). Physiol Biochem Zool 78: 10171025, 2005.

10. Claiborne JB, Edwards SL. Acid-base regulation in fishes: Cellular and molecular mechanisms. J Exp Zool 293: 302-319, 2002.

11. Cohen CS, Strathmann RR. Embryos at the edge of tolerance: Effects of environment and structure of egg masses on supply of oxygen to embryos. Biol Bull 190: 8-15, 1996.

12. Cronin ER, Seymour RS. Respiration of the eggs of the giant cuttlefish Sepia apama. Mar Biol 136: 863-870, 2000.

13. Diez JM, Davenport J. Embryonic respiration in the spiny dogfish (Scyliorhinus canicula L.). J Mar Biol Assoc UK 67: 249-261, 1987.

14. Esaki M, Hoshijima K, Kobayashi S, Fukuda H, Kawakami K, Hirose S. Visualization in zebrafish larvae of $\mathrm{Na}^{+}$uptake in mitochondria-rich cells whose differentiation is dependent on foxi3a. Am J Physiol Regul Integr Comp Physiol 292: R470-R480, 2007.

15. Evans DH, Piermarini PM, Choe KP. The multifunctional fish gill: Dominant site of gas exchange, osmoregulation, acid-base regulation, and excretion of nitrogenous waste. Physiol Rev 85: 97-177, 2005.

16. Fernandez M, Bock C, Pörtner HO. The cost of being a caring mother: the ignored factor in the reproduction of marine invertebrates. Ecol Lett 3: 487-494, 2000.

17. Fioroni P. Our recent knowledge of the development of the cuttlefish (Sepia officinalis). Zool Anz, 224: 1-25, 1990.

18. Gibbs A, Somero GN. $\mathrm{Na}^{+}-\mathrm{K}^{+}$-adenosine triphosphatase activities in gills of marine teleost fishes: changes with depth, size and locomotory activity level. Mar Biol 106: 315-321, 1990.

19. Goyal S, Vanden Heuvel G, Aronson PS. Renal expression of novel $\mathrm{Na} / \mathrm{H}$ exchanger isoform NHE8. Am J Physiol Renal Physiol 284: F467F473, 2003.

20. Grosell M. Intestinal anion exchange in marine fish osmoregulation. $J$ Exp Biol 209: 2813-2817, 2006.

21. Grosell M, Genz J, Taylor JR, Perry SF, Gilmour KM. The involvement of $\mathrm{H}^{+}$-ATPase and cerbonic anhydrase in intestinal $\mathrm{HCO}_{3}^{-}$secretion in seawater-acclimated rainbow trout. J Exp Biol 212: 1940-1948, 2009.

22. Guggino WBT. Salt balance in embryos of Fundulus heteroclitus and $F$. bermudae adapted to sea water. Am J Physiol 238: 42-49, 1980.

23. Gutowska MA, Melzner F. Abiotic conditions in cephalopod (Sepia officinalis) eggs: embryonic development at low $\mathrm{pH}$ and high $\mathrm{pCO}_{2}$. Mar Biol 156: 515-519, 2009.

24. Gutowska MA, Melzner F, Langenbuch M, Bock C, Claireaux G, Pörtner HO. Acid-base regulatory ability of the cephalopod (Sepia officinalis) in response to environmental hypercapnia. J Comp Physiol B 180: 323-335, 2010.

25. Hanlon RT, Messenger JB. Cephalopod Behaviour. Cambribge: Cambridge University Press, 1996.

26. Horng JL, Lin LY, Hwang PP. Functional regulation of $\mathrm{H}^{+}$-ATPase-rich cells in zebrafish embryos acclimated to an acidic environment. Am J Physiol Cell Physiol 296: C682-C692, 2009.

27. Hsiao CD, You MS, Guh YJ, Ma M, Jiang YJ, Hwang PP. A positive regulatory loop between foxi3a and foxi3b is essential for specification and differentiation of zebrafish epidermal ionocytes. PLos One 2: e302, 2007.

28. Hu MY, Sucré E, Charmantier-Daures M, Charmantier G, Lucassen M, Melzner F. Localization of ion regulatory epithelia in embryos and hatchlings of two cephalopods. Cell Tiss Res 441: 571-583, 2010.

29. Hu MY, Tseng YC, Stumpp M, Gutowska MA, Kiko R, Lucassen M, Melzner F. Elevated seawater $\mathrm{PCO}_{2}$ differentially affects branchial acidbase transporters over the course of development in the cephalopod Sepia officinalis. Am J Physiol Regul Integr Comp Physiol 300: R1100-R1114, 2011.

30. Hu MY, Yan HY, Chung WS, Shiao YC, Hwang PP. Acoustically evoked potential in two cephalopods infered using the auditory brainstem response (ABR) approach. Comp Biochem Physiol 153: 278-283, 2009.

31. Hwang PP. Ion uptake and acid secretion in zebrafish (Danio rerio). J Exp Biol 212: 1745-1752, 2009

32. Hwang PP. Salinity effects on development of chloride cells in the larvae of ayu Plecoglossus altivelis. Mar Biol 107: 1-7, 1990.
33. Hwang PP, Lee TH. New insights into fish ion regulation and mitochondrion-rich cells. Comp Biochem Physiol A 148: 479-497, 2007.

34. Hwang PP, Lee TH, Lin LY. Ion regulation in fish gills: recent progress in the cellular and molecular mechanisms. Am J Physiol Regul Integr Comp Physiol 301: R28-R47, 2011.

35. Hwang PP, Tsai YN, Tung YC. Calcium balance in embryos and larvae of the freshwater-adapted teleost, Oreochromis mossambicus. Fish Physiol Biochem 13: 325-333, 1994.

36. Katoh F, Tresguerres M, Lee KM, Kaneko T, Aida K, Goss GG. Cloning of rainbow trout SLC26A1: involvement in renal sulfate secretion. Am J Physiol Regul Integr Comp Physiol 290: R1468-R1478, 2006.

37. Lämmli UK. Cleavage of structural proteins during the assembly of the head of Bacteriophage T4. Nature 227: 680-685, 1970.

38. Larsen BK, Pörtner HO, Jensen FB. Extra- and intracellular acid-base balance and ionic regulation in cod (Gadus morhua) during combined and isolated exposures to hypercapnia and copper. Mar Biol 128: 337-346, 1997.

39. Lemaire J. Table de développement embryonaire de Sepia officinalis L (Mollusque Céphalopode). Bull Soc Zool Fr 95: 773-782, 1970.

40. Lin LY, Horng JL, Kunkel JG, Hwang PP. Proton pump-rich cell secretes acid in skin of zebrafish larvae. Am J Physiol Cell Physiol 290: C371-C378, 2006

41. Madan JJ, Wells MJ. Cutaneous respiration in Octopus vulgaris. J Exp Biol 199: 2477-2483, 1996.

42. Melzner F, Göbel S, Langenbuch M, Gutowska MA, Pörtner HO, Lucassen M. Swimming performance in atlantic cod (Gadus morhua) following long-term (4-12 month) acclimation to elevated seawater $\mathrm{PCO}_{2}$. Aquat Toxicol (Amst) 92: 30-37, 2009.

43. Melzner F, Gutowska MA, Langenbuch M, Dupont S, Lucassen M, Thorndyke MC, Bleich M, Pörtner HO. Physiological basis for high $\mathrm{CO}_{2}$ tolerance in marine ectothermic animals: pre-adaptation through lifestyle and ontogeny? Biogeosciences 6: 2313-2331, 2009.

44. Messenger JB, Nixon M, Ryan KP. Magnesium chloride as an anaesthetic for cephalopods. Comp Biochem Physiol 82: 203-205, 1985.

45. Nawata CM, Hirose S, Nakada T, Wood CM, Katoh A. Rh glycoprotein expression is modulated in pufferfish (Takifugu rubripes) during high environmental ammonia exposure. J Exp Biol 213: 3150-3160, 2010.

46. O'Dor RK, Webber DM. The constraints on cephalopods: why squid aren't fish. Can J Zool 64: 1591-1605, 1986.

47. Pörtner HO, Webber DM, Boutilier RG, O'Dor RK. Acid-base regulation in exercising squid (Illex illecebrosus, Loligo pealei). Am J Physiol Regul Integr Comp Physiol 261: R239-R246, 1991.

48. Packard A. Cephalopods and fish: the limits of convergence. Biol Rev 47: 241-307, 1972.

49. Pan TC, Liao BK, Huang CJ, Lin LY, Hwang PP. Epithelial $\mathrm{Ca}^{2+}$ channel expression and $\mathrm{Ca}^{2+}$ uptake in developing zebrafish. Am J Physiol Regul Integr Comp Physiol 289: R1202-R1211, 2005.

50. Perry SF, Gilmour KM. Acid-base balance and $\mathrm{CO}_{2}$ excretion in fish: Unanswered questions and emerging models. Respir Physiol Neurobiol 154: 199-215, 2006.

51. Pisam M, Rambourg A. Mitochondria-rich cells in the gill epithelium of teleost fishes: an ultrastructural approach. Int Rev Cytol 130: 191-232, 1991.

52. Potts WTW. Kinetics of sodium uptake in freshwater animals-a comparison of ion exchange and proton pump hypotheses. Am J Physiol Regul Integr Comp Physiol 266: R315-R320, 1994.

53. Robertson JD. Ionic regulation in some marine invertebrates. J Exp Biol 26: 182-200, 1949.

54. Romero MF, Fulton CM, Boron WF. The SLC4 family of $\mathrm{HCO}_{3}^{-}$ transporters. Eur J Physiol 447: 495-509, 2004.

55. Schipp R, Hevert F. Ultrafiltration in the branchial heart appendage of dibranchiate cephalopods: a comparative ultrastructural and physiological study. J Exp Biol 92: 23-35, 1980.

56. Schipp R, Mollenhauer S, Boletzky S. Electron microscopical and histochemical studies of differentiation and function of the cephalopod gill (Sepia officinalis L.). Zoomorphology 93: 193-207, 1979.

57. Schwartz AA, Allen JC, Harigaya S. Possible involvement of cardiac $\mathrm{Na}^{+} / \mathrm{K}^{+}$-adenosine triphosphatase in the mechanism of action of cardiac glycosides. J Pharmacol Exp Ther 168: 31-41, 1969.

58. Seibel BA, Drazen JC. The rate of metabolism in marine animals: environmental constraints, ecological demands and energetic opportunities. Philos Trans R Soc Lond B Biol Sci 362: 2061-2078, 2007. 
59. Soupene E, Inwood W, Kustu S. Lack of the Rhesus protein Rh1 impairs growth of the green alga Chlamydomonas reinhardtii at high $\mathrm{CO}_{2}$. Proc Natl Acad Sci USA 101: 7787-7792, 2004.

60. Soupene E, King N, Field E, Liu P, Niyogi KK, Huang CH, Kustu S. Rhesus expression in a green alga Chlamydomonas reinhardtii at high $\mathrm{CO}_{2}$. Proc Natl Acad Sci USA 99: 7769-7773, 2002.

61. Thomsen J, Gutowska MA, Saphörster J, Heinemann A, Trübenbach K, Fietzke J, Hiebenthal C, Eisenhauer A, Körtzinger A, Wahl M, Melzner F. Calcifying invertebrates succeed in a naturally $\mathrm{CO}_{2}$ enriched coastal habitat but are threatened by high levels of future acidification. Biogeosciences 7: 5119-5156, 2010.

62. von Boletzki S. Embryonic phase. In: Cephalopod Lifecycles, edited by Boyle RP. London: Academic Press, 1987, p. 5-31.

63. von Boletzki S. Ontogenetic and phylogenetic aspects of the cephalopod circulatory system. Experientia 43: 478-483, 1987.

64. Wagner CA, Finberg KE, Breton S, Marshanski V, Brown D, Geibel JP. Renal vacuolar-ATPase. Physiol Rev 84: 1263-1314, 2003.
65. Wang T, Yang CL, Abbiati T, Schultheis PJ, Shull GE, Giebisch G, Aronson PS. Mechanism of proximal tubule bicarbonate absorption in NHE3 null mice. Am J Physiol Renal Physiol 277: F298-F302, 1999.

66. Wells PR, Pinder AW. The respiratory development of atlantic salmon J Exp Biol 199: 2737-2744, 1996.

67. Wheatly MG, Henry RP. Extracellular and intracellular acid-base regulation in crustaceans. J Exp Zool 263: 127-142, 1992.

68. Whiteley NM, Scott JL, Breeze SJ, McCann L. Effects of water salinity on acid-base balance in decapod crustaceans. J Exp Biol 204: 1003-1011, 2001.

69. Winslow JL, Cooper RL, Atwood HL. Intracellular ionic concentration by calibration from fluorescence indicator emission spectra, its relationship to the $K_{\mathrm{d}}, F_{\min }, F_{\max }$ formula, and use with Na-Green for presynaptic sodium. J Neurosci Methods 118: 163-175, 2002.

70. Wu SC, Horng JL, Liu ST, Hwang PP, Wen ZH, Lin CS, Lin LY. Ammonium-dependent sodium uptake in mitochondrion-rich cells of medaka (Oryzias latipes) larvae. Am J Physiol Cell Physiol 298: C237C250, 2010.

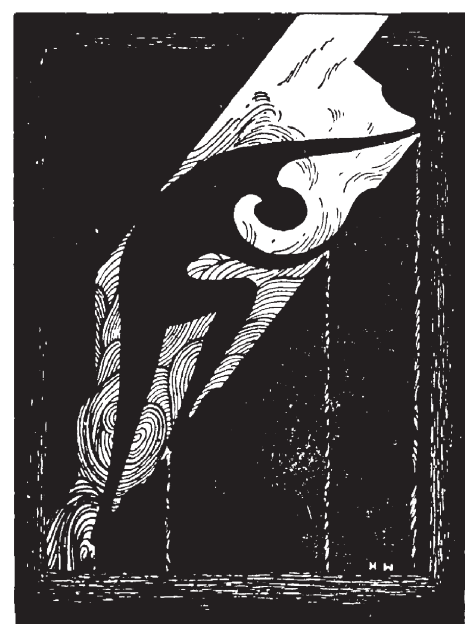

